\title{
RESEARCH IN CONSUMER PREFERENCES SELECTING THE SERVICES OF WELLNESS-FITNESS CENTRES IN KAUNAS
}

\author{
Vilma Tamulienè \\ Kaunas Faculty of Humanities, Vilnius University, Kaunas, Lithuania
}

\begin{abstract}
Research background and hypothesis. Competition among wellness-fitness centre companies is quite high. Each company which provides services to sport, in order to effectively carry out its activities, must take into account not only the political, economic, social, cultural, technological environment to follow current and potential competitors and their actions, but also consumer needs and priorities in selecting services. In addition, wellness-fitness centre managers must know the key criteria of consumer choice, especially when preparing strategic marketing plans for future company activities. Hypothesis - the most important keys of consumers selecting fitness centres services are geographic location, the quality of services and price.

Research aim was to determine consumer preferences in selecting fitness and wellness services at the largest health centres in Kaunas.

Research methods. The methods of quantitative questionnaire survey and observation were used, as well as the comparison of the conducted research findings with Euro barometer (2009), "Rait" (2007), KTU representatives investigating the customers in "Impuls" sports and entertainment parks (2009), Lithuanian Union of Sports Federations (LSFS) in 2010.

The questionnaire survey was conducted in March-April of 2011. A random probability sampling method was used with visitors $(\mathrm{n}=170)$ from four largest wellness-fitness centres in Kaunas and the e-version of the questionnaire was uploaded into the social network profiles of wellness-fitness centres. The data were analysed and processed using statistical package for social sciences (SPSS 17.0 version).

Research results. Results of the present research allow concluding that respondents' opinions concerning the following service assessment of wellness-fitness centres in Kaunas were very scattered and very unequal (standard deviation of the motivator assessment $>1$ ). However, only one provided service coincided. It was the service of sauna and sauna area (standard deviation of the motivator assessment $=0.996<1$ ). The research hypothesis was proved partially.

Discussion and conclusions. Having executed the research it was determined that there were very versatile consumer priorities in selecting the service provided by wellness-fitness centres in Kaunas and it was impossible to distinguish predominant ones proving that wellness-fitness centres had to focus on the personalized service packages and modern information technologies for the customer relationship management.
\end{abstract}

Keywords: consuming sports services, companies of sports services, package of services.

\section{INTRODUCTION}

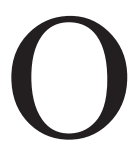
ver the past few years there have been many changes in sports service sector including: developments of technologies, growth of participation in sports activities. Competition among wellness-fitness centre companies is quite high. Each company which provides services to sport in order to effectively carry out its activities must take into account not only the political, economic, social, cultural, technological environment to follow current and 
potential competitors and their actions, but also consumer needs and priorities in selecting services. In addition, wellness-fitness centre managers must know the key criteria of consumer choice, especially when preparing strategic marketing plans for future company activities.

Searching for the answer to the main problem of article - what are the key criteria for consumers when they select services of wellness-fitness centres - is the aim of this scientific research. Some authors (Ryan, Deci, 2000; Arocas et al., 2005) analysed the issues concerning sports customers and their reasons for exercise. Consumer needs for sports were also analysed by W. Castellani et al. (2003), C. M. Frederick and C. S. Morrison (1996). Internal consumers' motivations are studied in the work by R. Oman and E. McAuley (1993).

Advantages of acquisition parameters in sports business were studied by G. T. Trail, J. D. James (2001), M. J. A. Berry and G. S. Linoff, (2004). Attitudinal issues in sports enterprises were investigated by M. J. A. Berry and G. S. Linoff (2004), sport consumer loyalty - by J. Lombardo (2005), S. Howard (2010) and others. J. Cooley (2004) analysed the service issues in sports service companies.

Internal consumers' physical exercise motivations were researched by R. Oman and E. McAuley (1993). Advantage obtainment parameters in sports companies were investigated by P. Chelladurai (2001), M. J. A. Berry and G. S. Linoff (2004). Approach building problems in sports companies were researched by M. J. A. Berry and G. S. Linoff, (2004), sport consumers' loyalty by J. Lombardo, (2005), E. C. Schwarz and J. D. Hunter (2008), G. T. Trail, J. D. James (2001) and others.

No empiric research concerning consumers' priorities selecting a sports club was found, although, there are some links to already executed research, e. g. under Euro barometer (2009) there was research about consumers' approach towards sport among the residents of the EU countries; however, Estonia was highlighted most among the Baltic States. Another study was carried out by the research agency "Rait" (2007) investigating the reasons for Lithuanian population not going in for sports. Another study carried out by KTU representatives investigated the customers in "Impuls" sports and entertainment parks (2009). It revealed the consumer behaviours related to sport club selection frequency and marketing measure which condition arising problems.
One more study was carried out under the order of Lithuanian Union of Sports Federations (LSFS) in 2010, where sport club employees and their competences providing sports services were researched. Thus, the research problem of this article concerns the sector providing sports services at the empirical level. Up to now it has not received adequate attention. In the sports sector it is important to store information concerning the present and potential consumers, their purchasing and consumption habits selecting the companies providing sports services.

Research object is current potential sport consumers' priorities of the services in wellnessfitness centres in Kaunas.

Research aim was to identify the most significant consumers' priorities in selecting the services provided by wellness-fitness centres in Kaunas.

Research objectives were as following:

1. Identify selection motivators for wellnessfitness centres;

2. Assess the significance of the provided services according to the consumers' approach in wellness - fitness centres.

Hypothesis: geographical place, the quality and price of the provided services are the most significant priorities for the consumers selecting the services provided by wellness-fitness centres.

\section{RESEARCH METHODS}

We chose the quantitative questionnaire survey method for the research of the empirical research problem. The research was carried in March-April, 2011, intervieweing the visitors from the largest wellness-fitness centres in Kaunas "Azžuolynas", "Linija", "Impuls", "Hermis" and the e-version of the questionnaire was uploaded into the social network profiles of wellness-fitness centres (www. facebook.com). According to the executives of wellness-fitness centres, there was no possibility to identify a precise number of persons going in for sports, as in the data bases there were more than 20000 people who had been going in for sports for the last 15 years, their memberships were still active and they were currently going in for sports, but it was necessary to check every consumer's membership separately. According to J. Vveinhardt (2007), (2006), in the descriptive research it is needed to survey not fewer than 150-200 people in order to gain reliable outcomes. 
Research sample. The scope of the research sample was 170: current and potential consumers of wellness-fitness centres. Table 1 reports presented demographical and socio-economics characteristics of the investigated respondents.
The respondents were surveyed at different time of the day so that it could be possible to identify the needs of different subjects. The data were analysed and processed with a statistical package for social sciences (SPSS 17.0 version).

Table 1. Demographic and socio-economic characteristics of respondents

\begin{tabular}{|c|c|c|c|}
\hline Demographic attributes & Socio-economic characteristics & Frequency & Ratio, \% \\
\hline \multirow{3}{*}{ Gender } & Man & 70 & 41 \\
\hline & Woman & 100 & 59 \\
\hline & Total: & 170 & 100 \\
\hline \multirow{7}{*}{ Age } & $>=18$ & 5 & 3 \\
\hline & $19-25$ & 68 & 40 \\
\hline & $26-35$ & 58 & 34 \\
\hline & $36-45$ & 24 & 14 \\
\hline & $46-55$ & 10 & 6 \\
\hline & 56 and more & 5 & 3 \\
\hline & Total: & 170 & 100 \\
\hline \multirow{7}{*}{ Income } & $>=500 \mathrm{Lt}$ & 15 & 9 \\
\hline & $501-1000 \mathrm{Lt}$ & 19 & 11 \\
\hline & $1001-1500 \mathrm{Lt}$ & 41 & 24 \\
\hline & $1501-2500 \mathrm{Lt}$ & 46 & 27 \\
\hline & $2501-4000 \mathrm{Lt}$ & 32 & 19 \\
\hline & $4001 \mathrm{Lt}$ and more & 17 & 10 \\
\hline & Total: & 170 & 100 \\
\hline \multirow{7}{*}{ Family status } & Single & 83 & 49 \\
\hline & Married & 49 & 29 \\
\hline & Living unmarried & 23 & 14 \\
\hline & Divorced & 10 & 6 \\
\hline & Married (living separately) & 3 & 2 \\
\hline & Widow(er) & 0 & 0 \\
\hline & Total: & 170 & 100 \\
\hline \multirow{11}{*}{ Education } & Unfinished basic & 3 & 2 \\
\hline & Primary & 2 & 1 \\
\hline & Unfinished secondary & 5 & 3 \\
\hline & Professional without the secondary & 0 & 0 \\
\hline & Secondary & 10 & 6 \\
\hline & Professional with the secondary & 5 & 4 \\
\hline & Unfinished College & 6 & 4 \\
\hline & College & 15 & 9 \\
\hline & Unfinished university & 17 & 10 \\
\hline & University degree & 107 & 62 \\
\hline & Total: & 170 & 100 \\
\hline \multirow{6}{*}{ Status } & Pupil & 6 & 4 \\
\hline & Student & 32 & 19 \\
\hline & Employee & 112 & 64 \\
\hline & Unemployed & 3 & 2 \\
\hline & Other & 17 & 9 \\
\hline & Total: & 170 & 100 \\
\hline
\end{tabular}




\section{RESEARCH RESULTS}

Analysing the priorities given by the consumers to the selection of wellness-fitness centres, we researched selection motivators for a sports club and the significance of the provided services according to the consumers' approach.

Selection motivators and their enhancement related to a wellness-fitness centre in Kaunas. The data about selection motivators to attend wellness-fitness centres in Kaunas are given in Figure 1. Key motivators when consumers were selecting a wellness-fitness centre proved to be the following: quality services (26\%), convenient geographical place $(24 \%)$ and affordable price (22\%). Qualified trainers (12\%) and diversity of services $(10 \%)$ had quite a great impact, too. Less meaningful in the consumers' selection of a place for sports were the prestige of a wellness-fitness centre (4\%), provided additional services $(6 \%)$ and neighbours' approach (4\%).

The deeper data analysis in the selection motivators of a sports club according to the strength has shown (see Table 2) that respondents' opinions were very united in the strength assessment of the following motivators in wellness-fitness centres (standard deviation of the motivator assessment $<1$ ): service diversity, service quality, price, trainers' and other employees' qualification and professionalism, trainers' and other employees' friendly communication with a visitor and a convenient geographical place.

The respondents' opinions varied only in the assessment of actions and special offer motivators (standard deviation of the motivator assessment $1.060>1)$.

The significance of the services provided by the wellness-fitness centres in Kaunas according to the consumers' approach. Figure 2 provides data concerning the significance of the provided services for the consumers of wellnessfitness centres in Kaunas. The obtained research data show that the most significant services for respondents were as follows: swimming pool and water area, sauna and sauna area, parking lot, Jacuzzi, and cloakroom for outdoor clothing. The least significance for consumers was the rent of equipment as well as workouts for children and pregnant women.
Figure 1. Distribution of the motivators influencing consumers' selection of a wellness-fitness centre in Kaunas

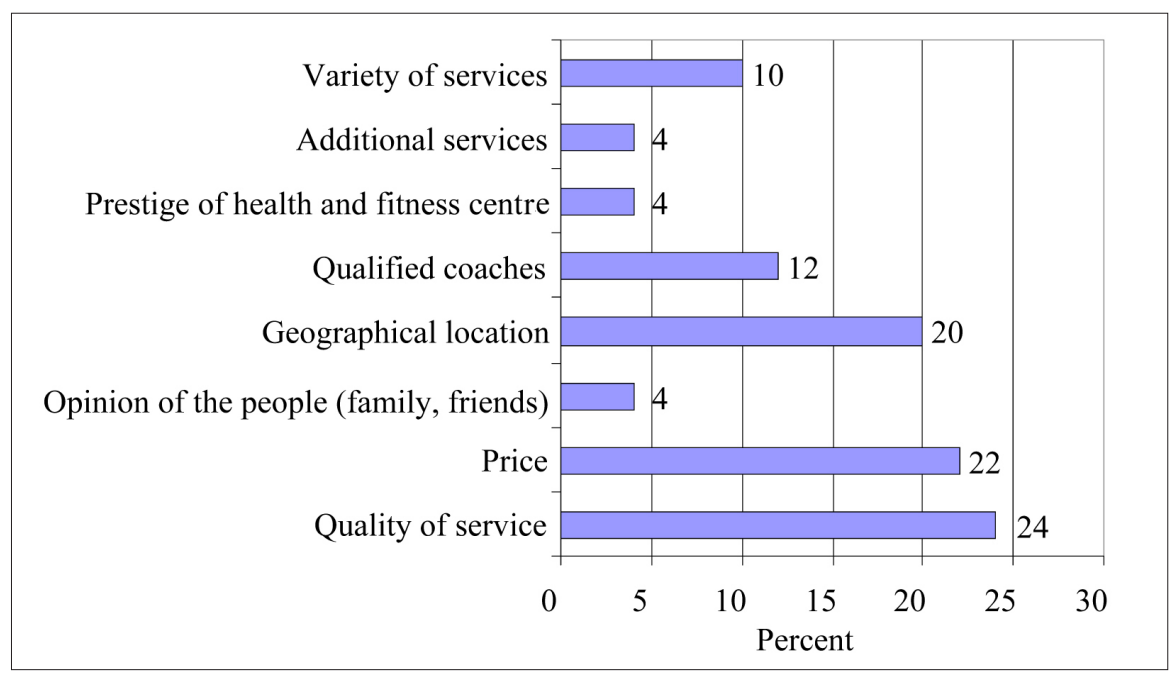

\begin{tabular}{|c|c|c|c|c|c|c|c|c|}
\hline \multicolumn{2}{|c|}{$\begin{array}{l}\text { Statistical } \\
\text { indicators }\end{array}$} & $\begin{array}{c}\text { Variety } \\
\text { of } \\
\text { services }\end{array}$ & $\begin{array}{l}\text { Quality } \\
\text { of } \\
\text { services }\end{array}$ & Price & $\begin{array}{l}\text { Promotions } \\
\text { \& special } \\
\text { offers }\end{array}$ & $\begin{array}{c}\text { Qualified } \\
\text { coaches }\end{array}$ & $\begin{array}{c}\text { Staff friendly } \\
\text { communication } \\
\text { with customers }\end{array}$ & $\begin{array}{l}\text { Geographical } \\
\text { location }\end{array}$ \\
\hline $\mathrm{N}$ & Valid & 170 & 170 & 170 & 170 & 170 & 170 & 170 \\
\hline \multicolumn{2}{|c|}{ Mean } & 1.66 & 1.38 & 1.59 & 2.19 & 1.75 & 1.65 & 1.79 \\
\hline \multicolumn{2}{|c|}{$\begin{array}{l}\text { Std. } \\
\text { Deviation }\end{array}$} & 0.785 & 0.626 & 0.796 & 1.06 & 0.922 & 0.765 & 0.929 \\
\hline \multicolumn{2}{|c|}{ Variance } & 0.617 & 0.391 & 0.634 & 1.124 & 0.85 & 0.585 & 0.863 \\
\hline
\end{tabular}

Table 2. The motivator strength for consumers selecting a wellnessfitness centre in Kaunas 
However, after having carried out a deeper significance analysis of the assessment related to the provided services (see Table 3), it was noticed that the respondents' opinions were very unequal (standard deviation of the motivator assessment $>1$ ).
However, only one provided service coincided. It was a service of sauna and sauna area (standard deviation of the motivator assessment $=0.996<1$ ). The respondents' opinions concerning the following service assessment of wellness-fitness centres in Kaunas were very scattered.

\begin{tabular}{|l|c|c|c|}
\hline \multicolumn{1}{|c|}{ Services } & Mean* & $\begin{array}{c}\text { Std. } \\
\text { Deviation** }\end{array}$ & Variance \\
\hline Swimming pool and water area & 1.84 & $\mathbf{1 . 0 7 5}$ & 1.156 \\
\hline Sauna, sauna area & 1.88 & 0.996 & 0.992 \\
\hline Parking lot & 2.05 & $\mathbf{1 . 0 5 9}$ & 1.122 \\
\hline Children' room & 3.42 & $\mathbf{1 . 3 0 8}$ & 1.712 \\
\hline Massage cabinet & 2.84 & $\mathbf{1 . 2 9 5}$ & 1.677 \\
\hline Solarium & 3.05 & $\mathbf{1 . 2 7 9}$ & 1.636 \\
\hline Workouts for children & 3.49 & $\mathbf{1 . 2 5 1}$ & 1.565 \\
\hline Workouts for pregnant women & 3.39 & $\mathbf{1 . 3 1 6}$ & 1.731 \\
\hline Shop of equipment & 3.56 & $\mathbf{1 . 2 1 1}$ & 1.466 \\
\hline Jacuzzi & 2.26 & $\mathbf{1 . 2 2 9}$ & 1.509 \\
\hline Cloakroom outdoor clothing & 2.33 & $\mathbf{1 . 1 9 1}$ & 1.417 \\
\hline Cafe & 2.66 & $\mathbf{1 . 2 6}$ & 1.587 \\
\hline Pool workouts & 2.64 & $\mathbf{1 . 1 8 5}$ & 1.405 \\
\hline Equipment rent & 3.28 & $\mathbf{1 . 2 1 7}$ & 1.482 \\
\hline Outdoor sports & 2.84 & $\mathbf{1 . 2 9 3}$ & 1.673 \\
\hline VIP zone & 3.27 & $\mathbf{1 . 3}$ & 1.69 \\
\hline
\end{tabular}

Table 3. Significance assessment of consumers' service in wellnessfitness centres in Kaunas

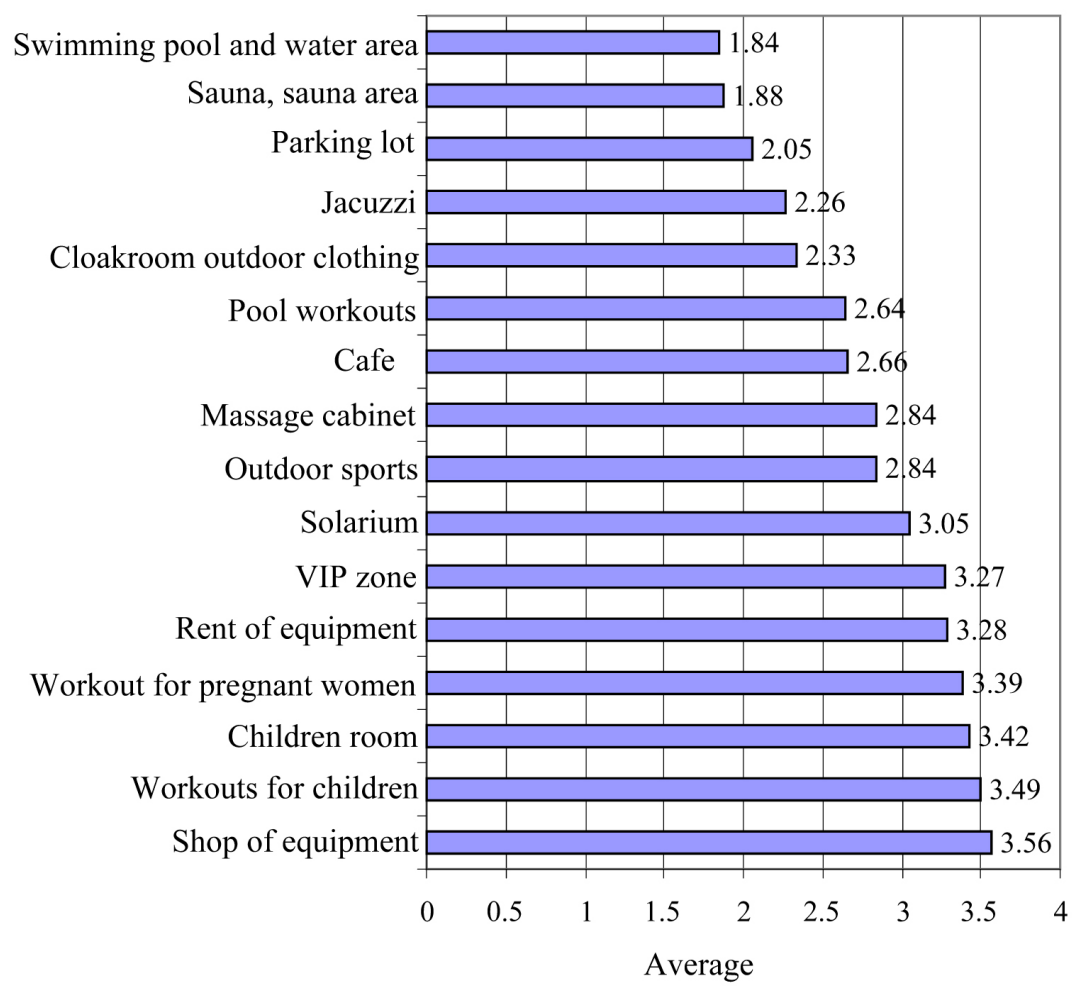

Figure 2. Significance assessment of the services provided by the wellness-fitness centres in Kaunas
Note. $*$ - mean - reveals average significance assessment of every aspect; ** - Std. Deviation - standard deviation. The smaller it was, the more unanimously respondents assessed the factor. 


\section{DISCUSSION}

After having carried out quantitative research it can be claimed that the consumers in wellnessfitness centres according to demographic indexes are very versatile as both men and women go in for sports similarly: from a young one to an old one. However, according to the age groups, consumers vary from 19 to 35 years. There are also small numbers of schoolchildren and pensioners, so we might presume that in order to attract the following population, greater attention should be paid to it. According to socio-economic factors, it was found that most consumers of wellness-fitness centres in Kaunas were employed, educated and intelligent people, who had their own aims and needs in life. Besides, wellness-fitness centres are attended by people possessing different income and belonging to different social layers. Most consumers spend about one hundred LTL on sports monthly. However, the distribution of the spent income depends on the sports time, chosen membership, attendance frequency and gained discounts; thus, in order to ensure the efficiency of activity, it is important to design service packages complying with consumers' possibilities and wishes.

Selection motivators of wellness-fitness centres among consumers. The obtained outcomes of the priorities made by the consumers in wellness-fitness centres in Kaunas for the selection of a sports club, it was identified that there were three key motivators and they were related to the marketing means, i. e. price, product/service and geographical place. However, it should be noted that the geographical position is a strategic decision of marketing and it has to be taken into consideration before the establishment of clubs. This is also suggested by the research data carried out in Impuls (KTU representatives investigating the customers in "Impuls" sports and entertainment parks (2009)): the price, product/service and geographical position are important for sports and fitness consumers. However, the in-depth analysis by KTU (2009) does not show the consumer choices of services. It is not clear whether the distinguished criteria like price, product/service and geographical place are predominant. The deeper analysis showed that consumers unanimously excluded the motivators, such as service quality, geographical position and price. Such motivators as actions and special offers are not strong in order to influence consumers' selection. Special offers and actions affect various consumers differently, thus promotional actions have to be adapted to consumer's individual needs.

The significance of the services provided by wellness-fitness centres in Kaunas according to the consumers' approach. The consumers' opinions concerning the provided services revealed that swimming pool and water area, sauna and sauna area, parking lot, Jacuzzi, and cloakroom for outdoor clothing were significant. However, the deeper analysis showed that the choices of those services were scattered among consumers. The most significant priority selecting a sports club was sauna and different services. It means that sports clubs have to provide personalized service packages for consumers and those have to include a sauna, and other services have to be included according to individual needs. The following assessment enables the claim that the consumers' distribution assessing various service differs a lot, thus the employees of wellness-fitness centres have to design service packages for consumers of wellness-fitness centre and it requires more information concerning each consumer and his/her needs.

The consumers' selection priorities concerning the services provided by wellness-fitness centres in Kaunas depends on three motivators: sauna and various services which also depend on sport consumer's habits, needs and motivation. In this service sector, the service package has to be developed taking into consideration consumer's individual lifestyle habits and needs. Designing a service package for a consumer it is important to identify and select such services which comply with different consumers' needs as the importance of the provided services differs for individual consumer.

\section{CONCLUSION AND PERSPECTIVES}

There are very different consumer priorities for selecting the services provided by wellness-fitness centres in Kaunas. This proves that wellness-fitness centres have to focus on the personalized service packages and modern information technologies for the relationship management with consumers. The further research perspectives would be related to the application of information technologies in wellness-fitness centres in Kaunas storing data about consumers and designing personalized service packages for them. 
The research hypothesis was proved partially. The key motivators selecting wellness-fitness centres in Kaunas were the following: geographical position, service quality and price. However, a deeper research analysis has revealed that the price of wellness-fitness centres has to be adapted to individual consumers and there have to be designed different value service packages in order to attract and maintain consumers and ensure the employment of organizations.

Wellness-fitness centres in Kaunas have to remain innovative and foresee possible personalized service packages for consumers in future. Consumers are demanding and searching for new experience, thus in order to satisfy their needs there is a necessity to personalize the package of the provided services.

In order to design and secure good consumers' management system in companies, information technologies have to be installed to store data concerning every consumer's needs for sport. That would enable organizations to design individual service packages for consumers.

\section{REFERENCES}

Arocas, Luna, R., Tang, Li-Ping, T. (2005). The use of cluster analysis to segment clients of a sport center in Spain. European Sport Management Quarterly, Taylor \& Francis, 4 (5), 301-308.

Berry, M. J. A., Linoff, G. S. (2004). Data Mining Techniques: For Marketing, Sales, and Customer Relationship Management $\left(2^{\text {nd }}\right.$ ed.) Indiana: Wiley Publishing, Inc.

Castellani, W., Ianni, L., Ricca, V., Mannucci, E., Rotella, C. M. (2003). Adherence to structured physical exercise in overweight and obese subjects: A review of psychological models. Eating and Weight Disorders, 8, $1-11$.

Chelladurai, P. (2001), Managing Organizations for Sports And Physical Activity: A Systems Perspective. Holcomb Hathaway Pub. Scottsdale.

Cooley, J. (2004). How to Hug Your Customers, and Get Value with Every Squeeze. Customer think Corporation [2012 01 20]. Internet link http://www.crmtrends.com/ crm.html

Eurobarometro tyrimas. (2009). ES piliečių požiūris i sportą ir fizinę veiklą labai skiriasi [2012 03 04]. Internet link http://europa.eu/rapid/pressReleasesAction.do?refe rence $=\mathrm{IP} / 10 / 383 \&$ format $=$ HTML\&aged $=1$ \&language $=$ LT\&guiLanguage $=$ en

Europos komisijos atlikti tyrimai. (2007). [2012 03 04]. Internet link http://ec.europa.eu/culture/pdf/doc960 en.pdf,

Frederick, C. M., Morrison, C. S. (1996). Social physique anxiety: Personality constructs, motivations, exercise attitudes, and behaviours. Perceptual and Motor Skills. 82, 963-972.

Howard, S. (2010), Changing Customer Values. Howard Marketing Services. [2012 08 27]. Internet link http://www.salesvantage.com/article/392/ChangingCustomer-Values

„Impuls" sporto ir pramogu parkuose klientu tyrimai, atlikti KTU atstovu. (2009). [2012 08 27]. Internet link http:/www.impuls.lt/lt/bendras/ naujienos? item $=199 \&$ page $=1$

Lietuvos sporto federaciju sajungos (LSFS) tyrimas. (2010). Sporto vadybininkams trūksta žinių ir igūdžių [2012 03 04]. Internet link http://www.diena.lt/naujienos/ sportas/tyrimas-sporto-vadybininkams-truksta-ziniu-irigudziu-303617

Lombardo, J. (2005). A new ball game in South Florida: Heat puts twist on marketing. Street \& Smith's Sports Business Journal, 9, 42-51.

Oman, R., Mcauley, E. (1993). Intrinsic motivation and exercise behavior. Journal of Health and Education, 24, 232-238.

Ryan, R. M., Deci, E. L. (2000). Intrinsic and extrinsic motivations: Classic definitions and new directions. Contemporary Educational Psychology, 25, 54-67.

Schwarz, E. C., Hunter, J. D. (2008). Theory and Practice in Sport Marketing. Oxford, UK: Elsevier.

Trail, G. T., James, J. D. (2001) The motivation scale for sport consumption: Assessment of the scale's psychometric properties. Journal of Sport Behaviour, 24 (1) 108-127. 


\title{
VARTOTOJŲ PRIORITETAI RENKANTIS KAUNO SVEIKATINGUMO CENTRU TEIKIAMAS PASLAUGAS
}

\author{
Vilma Tamulienè \\ Vilniaus universiteto Kauno humanitarinis fakultetas, Kaunas, Lietuva
}

\section{SANTRAUKA}

Tyrimo pagrindimas ir hipotezė. Kiekviena sporto paslaugas teikianti imoné, norėdama sékmingai vykdyti savo veiklą, turi atsižvelgti ne tik ỉ politinę, ekonominę, socialinę, kultūrinę, technologinę aplinką, ỉvertinti esamus ir galimus konkurentus bei jų veiksmus, bet ir vartotoju poreikius, prioritetus renkantis paslaugas. Sveikatingumo centrų vadovams, sudarant strateginius rinkodaros planus, svarbu žinoti, kurie kriterijai renkantis sveikatingumo centru paslaugas vartotojams yra pagrindiniai. Empirinio tyrimo apie vartotojų prioritetus renkantis sporto klubą nepavyko rasti, nors sąsajų yra su jau atliktais. Pavyzdžiui, Eurobarometras (2009) tyrẻ vartotojų požiūrị i sportą tarp ES šalių gyventojų, tačiau jame iš Pabaltijo šalių labiau akcentuojama Estija. „Rait“ tyrimo agentūra (2007) tyrẻ Lietuvos gyventojų nesportavimo priežastis. Kitas tyrimas atliktas apklausus KTU „Impuls“ sporto ir pramogų parkų klientus (2009) ir bandant išsiaiškinti vartotojų sporto klubų pasirinkimo dažnumą ir veiklos priemones, lemiančias ši pasirinkimą. Straipsnyje keliama moksline hipotezé: vartotojams renkantis sveikatingumo centru teikiamas paslaugas svarbiausia yra geografinè vieta, teikiamų paslaugų kokybė ir kaina.

Tikslas - nustatyti vartotojų prioritetus renkantis sporto ir sveikatingumo paslaugas didžiuosiuose Kauno sveikatingumo centruose.

Metodai. Tyrimo metu taikyti tokie metodai: pirminis - kiekybinis, anketinès apklausos; antrinis - atliktu tyrimų apžvalgos ir palyginimo.

Rezultatai. Vartotojų prioritetai renkantis Kauno sveikatingumo centrų teikiamas paslaugas labai ịvairūs ir nẻra imanoma išskirti vyraujančiu.

Aptarimas ir išvada. Sporto ir sveikatingumo centrai turi orientuotis $\mathfrak{i}$ asmeninius paslaugų paketus. Čia jiems pagelbèti galètų ryšių su klientais valdymo šiuolaikinès informacinès technologijos.

Raktažodžiai: sporto paslaugų vartojimas, sporto paslaugas teikiančios įmonès, paslaugų paketas.

Gauta 2013 m. vasario 7 d.

Received on February 7, 2013 